\title{
Providing Library Support to Off-Campus Programs
}

Marie Kascus and William Aguilar

Given the demographic projections for the next decade, many academic institutions will turn to off-campus programs as a means to redress declining enrollments. Library services to offcampus programs must be reconsidered in view of the anticipated proliferation of those programs and the unique problems they encounter. Special consideration must be given to the concerns posed by accreditation and licensing bodies and the further impact of technology on distance learning.

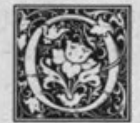

ff-campus programs make it possible for academic institutions to serve those individuals who are unable or unwilling to become full-time day students by providing programs at times and locations outside the usual range of offerings. Offcampus programs also make it possible for academic institutions to counteract declining full-time enrollment and thus to remain financially solvent. These programs usually generate significant revenue relative to the amount invested in them. Some institutions have reaped substantial benefits from off-campus programs without giving full attention to providing offcampus students with the same level of services available to on-campus students. In addition, there is some concern about the equivalence of academic requirements for off-campus and on-campus students and of the degrees awarded each group.

Of primary concern is the quality of offcampus education. Nowhere is this concern better demonstrated than in the area of library services. Library support is an integral part of quality education and a vital service which should be available to all students, whether on-campus or offcampus. A related issue is that off-campus students pay the same or higher tuition and are, therefore, entitled to equivalent library services. Traditional academic values should be maintained no matter where instruction is being offered. Regional accrediting bodies, state licensure agencies, and the courts are lending support to ensure the quality of off-campus programs, including the library services offered.

The delivery of off-campus library services is recognized as a difficult problem, yet the accrediting associations expect institutions to find ways to provide services. The implication is that, as new off-campus programs are developed, the library component will be examined much more carefully than it has been in the past. Even though some institutions have attempted to solve through innovative methods the problem of providing library services, in fact many academic librarians have given little thought to the special needs of students enrolled in off-campus programs. The existence of the annual Off-Campus Library Services Conference attests to one group's heightened awareness of a common concern. ${ }^{1}$ Addressing the special needs of this growing group of students will become an issue of increasing impor- 
tance to academic librarians as off-campus programs expand further.

What follows is a discussion of the background on the proliferation of off-campus programs; the involvement of accrediting associations, licensing agencies, and the courts in the extended campus; some problems and practices related to the delivery of library services at a distance; and a working model for off-campus library support.

\section{BACKGROUND}

Although off-campus programs have a long history, the current surge of interest in extending academic services did not begin in earnest until the early 1970 s. Alan Pifer, then president of the Carnegie Corporation, argued that academic institutions should offer external degrees in order to meet the educational needs of a learned society. ${ }^{2}$ Although the rationale for off-campus programs has not changed dramatically during the intervening decade, the need for academic institutions to offer these programs has never been more critical. Ironically, the proliferation of offcampus centers has become one of the most emotional issues in higher education. Patricia Cross and Anne-Marie McCartan indicate that the issue of assuring quality education in off-campus programs has been a source of acrimony within the formal educational system. ${ }^{3}$

Off-campus education is an idea that typically evokes biased attitudes and knee-jerk reactions. Faculty in general are opposed to the concept and have considered off-campus programs to be secondrate. From the on-campus faculty perspective, off-campus programs are perceived to be of lesser importance; off-campus programs are perceived to be a threat; and off-campus students are perceived to be less serious. ${ }^{4}$ The failure of faculty to recognize the viability and potential of the off-campus student has contributed to the low status of off-campus programs and has prevented these programs from being fully integrated into the higher education mainstream. The issue of quality control will remain a major obstacle in the path toward recognition and full acceptance of off-campus programs as long as they remain outside the mainstream. In order to begin to respond adequately to offcampus needs, it is necessary to separate myth from reality and to establish a common ground for discussion and a springboard for action.

At first glance, it may seem as if the problem affects only a limited audience. However, indications are that off-campus education is an expanding market. Even those institutions which have historically limited instruction to on-campus may soon find themselves entering the offcampus market for pragmatic reasons related to changing demographics and enrollment patterns. Forecasters have painted a picture in which the pool of traditional full-time students aged $18-22$ is diminishing. By the year 2000 , fifty percent of the population is expected to be age 35 or over; the student population in higher education institutions will experience an eighteen-percent decrease in fulltime enrollment and an eight-percent increase in part-time enrollment. ${ }^{5}$ According to Harold Hodgkinson, the number of young people is on the decline and, within the youth cohort, the percentage who graduate from high school is diminishing. The competition for full-time students will become acute as a result of this diminishing population, and off-campus programs will be viewed as a means of stabilizing or increasing enrollment. ${ }^{6}$

\section{".. . academe can continue to expect competition from what Lusterman re- fers to as the 'shadow educational system'."}

The problem for academe extends beyond the diminishing pool of collegebound students. The competition from other providers of education poses an additional challenge. The National Center for Educational Statistics reported that, in 1982 , the formal school system provided some two-thirds of all adult education courses. ${ }^{7}$ Cross mentions four noncollege institutions in the Boston area that have been authorized by the State of Massachusetts to grant associate, baccalaureate, or 
master's degrees to anyone meeting their requirements for admissions. ${ }^{8}$ The Massachusetts experience suggests that the distinction between the training programs offered by business and industry and the education programs offered by postsecondary institutions is blurring. This crossover indicates that academe can continue to expect competition from what Seymour Lusterman refers to as the "shadow educational system."'9

Given the changing demographics, the competition for students, and the competition from other providers of education, it seems likely that more institutions will turn to off-campus programs as a way of preserving the status quo and remaining competitive and financially solvent. The issues and problems related to off-campus education and library support are, however, not solely economic. While offcampus education is an economic issue for some institutions, it is the quality of the academic experience that should concern academe as a whole. The library is a key component of quality education, and academic institutions have a responsibility to provide off-campus students with resources and facilities equivalent to those of their on-campus peers. Therefore, it is critical that off-campus programs be integrated into the higher education infrastructure. Only then will quality assurance and adequate library support be provided.

\section{ROLE OF ACCREDITING AND LICENSING ASSOCIATIONS IN OFF-CAMPUS PROGRAMS}

The accrediting associations, seeing the proliferation of off-campus programs, have attempted to establish a measure of control. In the fall of 1976, the Council of Postsecondary Accreditation reported significant evidence of inferior off-campus programs and encouraged the regional accrediting agencies to deal with the problem through the policy process. ${ }^{10}$ The Northwest Association of Schools and Colleges took the lead with its policy mandating that colleges obtain prior approval before establishing off-campus programs. ${ }^{11}$ The policy was intended to insure a need for the program, to incorporate the program into the formal evaluation pro- cess, and to remind institutions that offcampus programs are not automatically covered under their overall accreditation. The actions calling for stricter regulations of off-campus programs represent the regional accrediting authorities' efforts to influence the future development of offcampus education. While the rules and regulations may be viewed as bureaucratic interference, they can provide the measure of quality assurance needed to bring off-campus programs into the higher education mainstream.

The accreditation standards of the New England Association of Schools and Colleges, the North Central Association, the Northwest Association, the Southern Association, the Western Association, and the Middle States Association all include a provision calling for the adequacy of library and learning resources and the importance of access at times convenient for off-campus students. ${ }^{12}$ The statements of the regional associations are unanimous in their concern about off-campus library support, recognizing the importance of libraries to the quality of all instruction.

At the state level, regulations for licensure and accreditation specifically mention adequate library resources. The language of the regulations varies from state to state, as does the application of the rules, but the concern for library resources is a theme common throughout the nation. Of paramount importance are the recent state regulations specifically directed at insuring library support for off-campus programs as part of the accreditation process. For example, Connecticut's revised 1986 regulations specify library requirements which must be met before offcampus programs will be licensed. The basic premise of the regulations is that off-campus programs will provide the following: (1) core collections; (2) reserve reading collections; (3) professional library staff; (4) supplementary materials; (5) adequate funds; and (6) access to adequate facilities. ${ }^{13}$ Other states, such as North Carolina, have implemented similar regulations. ${ }^{14}$

The full consequences of these new regulations have yet to be determined. Critics argue that the regulations create additional financial burdens; that academic in- 
stitutions will be forced to curtail offcampus programs; that ultimately they may force small institutions out of business; and that students, enrolled in programs where the revenue does not justify the expense of off-campus library support, will suffer as a result of discontinued programs. Conversely, supporters contend that the regulations are long overdue and that the library needs of off-campus students and faculty will only be met when fiscal officers are forced to allocate funds for that purpose. Whether this type of regulation becomes the norm remains to be seen. However, it is clear that state licensing agencies are not ignoring offcampus programs and in fact are keenly interested in providing the same standard of quality for both off-campus and oncampus programs.

From a legal perspective, a court case involving Nova University supports the trend toward strengthening standards for licensure and accreditation and reaffirms the importance of libraries in the higher education process. The case involved one of Nova's external degree programs, the doctorate of public administration, to be operated in the District of Columbia. As part of this program, students are expected to complete a series of research papers and a final analytical project considered equivalent to a doctoral dissertation. Nova was denied license in large part because the commission found that Nova had no library in the District of Columbia and no plans to establish one. The specific regulations require that the library have a collection of books adequate for the needs of the particular program offered; continuing acquisitions of current library materials; professional, trained staff; and adequate seating and work space. ${ }^{15}$ The commission interpreted the regulations to mean that an educational institution had to establish its own library rather than rely on other libraries. ${ }^{16}$ Nova's plan to use the George Mason and Howard University Libraries to meet the District's requirements was deemed insufficient. This position seems to imply that the only way to satisfy the library support component of offcampus library education is by establishing a library at the site. This is a strong ar-
"... off-campus students are entitled to the same level of library services provided for on-campus students. ..."

gument for library support, but may be an extreme requirement given the cost and the availability of other options.

Accreditation operates to ensure program or institutional quality and provides a benchmark for improving both the program and the institution. The value of the accreditation process lies in its ability to preserve universal standards of excellence without stifling institutional creativity and program innovation. If library services at a distance can be provided in new and innovative ways, the requirements can be satisfied. The accrediting bodies are ensuring that libraries provide services, not actually dictating procedures.

\section{MANY PROBLEMS/SOME SOLUTIONS TO THE DELIVERY OF OFF-CAMPUS LIBRARY SERVICES}

In looking to the future of higher education and the anticipated growth of the expanded campus, it is important to recognize that off-campus students have special needs; off-campus students are entitled to the same level of library services provided for on-campus students; and the library's role in the educational process is to facilitate independent learning for both offcampus and on-campus students. A recent Carnegie report states, "The quality of a college is measured by the resources for learning on the campus and the extent to which students become independent self-directed learners. ${ }^{17}$ This is a timely reminder of the importance of libraries in the educational process and will be a focal point for the discussion of problems and current solutions in the delivery of offcampus library services.

Academic institutions with off-campus programs face difficult problems in providing library support. The solutions chosen vary from institution to institution and range from total neglect to spoon-feeding. 
The existence of any delivery system for off-campus library services is progress in itself and suggests that the unique needs of off-campus students and faculty are at least being recognized. The problems for the library just begin with the recognition of these special needs and the commitment to address them.

The first and most critical problem is to provide access to bibliographic tools, collections, and trained staff. Some of the traditional solutions to this problem have been to establish branch libraries at the site; to use the on-campus library to serve all users; to use the trunk delivery system to transport materials to remote sites; to use local libraries at the remote site; or to use some combination of these options. ${ }^{18}$

Branch libraries established to serve offcampus sites are usually limited to those locations that ensure a consistently high enrollment. The expense of establishing a branch library and the resultant duplication of resources are powerful deterrents. In establishing branch libraries, there are necessary limitations in the size and scope of the collection available at the offcampus site. As such, off-campus students would not have available the full range of library materials needed for browsing, researching, and identifying those materials relevant to their needs. Consequently, these students are at an academic and intellectual disadvantage in comparison with on-campus students.

A second option is the use of the oncampus or home library for all users. This option requires the home library to assume full responsibility for being the primary source of information for those involved in off-campus programs. The extent of the services that can be provided varies from institution to institution and is dependent on the level of awareness of the special needs of off-campus faculty and students and the level of commitment to addressing those needs. Some of the services provided from the home library include a toll-free number to link offcampus with on-campus; access to research and reference service; renewal of books by telephone; photocopy service for journal articles; interlibrary loan; computer subject searches; and bibliographic instruction. Any of these services can be provided, but not without budgetary support above the level of funding allocated to the home library. If the home library is expected to provide these services without additional staff and funds, it would have to be done at the expense of the oncampus library program.

Among academic librarians there is a general sense that off-campus programs divert funds from on-campus users who are already underserved. These programs represent an additional financial burden on the already overtaxed library budget and contribute to the perceived erosion of the quality of services available to oncampus users. This perception, accurate or not, must be addressed in considering the provision of library services to offcampus programs.

A third option is to use a trunk delivery system. This involves transporting books, photocopies, audiovisual equipment, etc., in the trunk of a car or in a van, much the way public libraries use bookmobiles. All the materials needed to support the academic program are brought to the site. Library materials are transported in this manner most often by an officer of the extension school. The trunk delivery system is cumbersome and limits delivery to necessary and specific materials. A major drawback is that it does not provide access to the tools needed to perform even rudimentary research, thereby limiting a student's library and educational experience. If access is limited to course-specific materials that can readily be transported in the trunk of a car or in a van, the student does not have the opportunity to experience the full range of library materials available.

A fourth option is the use of local libraries at the off-campus site. This option involves a contractual arrangement with an area library at a given site to provide access to facilities to support off-campus programs. One major drawback is that local public libraries are often unable to support college-level work. Beyond that, home institutions have often been unable to locate other colleges or universities willing to enter into contractual agreements to allow access to their library resources and 
facilities. On principle an academic institution may be unwilling to enter such a contractual agreement for fear it might jeopardize its own competitiveness in the recruitment of students. Use of this option as a total delivery system places control outside the institution and could be viewed as a surrendering of responsibility.

These four options, or some combination thereof, have been used to address the primary problem of providing access to collections, facilities, and trained staff for off-campus faculty and students.

A second problem area in providing offcampus library support is document delivery. Programs offered at a distance require complex delivery systems. Book and document delivery, both outgoing and incoming, poses problems. Trunk delivery physically limits the number of items that can be delivered at one time. Use of the U.S. Postal Service can result in delays in receiving material, a high cost per transaction, and practical problems in returning borrowed books. Technology, such as telefacsimile, can help to shorten the distance between the library and the user, but ultimately cost becomes the critical factor in determining the choice of the delivery system.

A third problem area in providing offcampus library support is timeliness. Speed is of the essence in serving users; at a distance, the time factor becomes even more critical. Most library users want an immediate response to a request for information or resources, whether on-campus or off-campus. Timeliness in responding to an information request would be an important measure of library performance in the user's evaluation of library services.

A fourth problem area in offering academic programs at remote sites is that faculty may be reluctant to make library assignments to off-campus students. Yet, the faculty should be responsible for preparing library assignments that will give off-campus students an equivalent educational experience and satisfy the same standards of rigor applied to on-campus programs. The library's responsibility is to work to establish its presence and insure that off-campus faculty are fully aware of the library support available for the instructional program. In order to do this, the library should develop a good marketing strategy that alerts off-campus faculty to the full range of library resources and services that are available and how these can be packaged and delivered to serve off-campus needs.

\section{"The 'ACRL Guidelines for Ex- tended Library Services' represents the library world's best contribution to quality assurance in off-campus li- brary programs."'}

The problems in delivering off-campus library services are many and complex. The solutions must be flexible and adaptable to a wide spectrum of academic programs. This underscores the need for a common standard that ensures excellence in off-campus library support. The "ACRL Guidelines for Extended Library Services" represents the library world's best contribution to quality assurance in off-campus library programs. ${ }^{19}$ Their status as guidelines and not standards, however, diminishes their overall impact and effectiveness. Given current enrollment trends and the proliferation of off-campus programs, ACRL may want to consider modifying the guidelines and upgrading them to standards. This would underline the profession's commitment to the role of libraries in off-campus education and would provide a common standard for responding creatively and effectively to the library needs of a wide diversity of offcampus programs.

\section{OTHER DIRECTIONS: A WORKING MODEL FOR OFF-CAMPUS LIBRARY SERVICES}

The fundamental focus of any library is service. In off-campus programs, service takes on an even greater significance because students are geographically removed from the main campus. Creativity and innovation become more important. 
Until now, all of the strategies for delivering off-campus library support have been the result of individual institutions' creative solutions to local problems. What is needed is a systems approach addressing the special needs of off-campus students and faculty in a comprehensive way.

The working model which follows consists of three separate but complementary parts requiring use of the home library, a designated off-campus librarian, and agreements with nonaffiliated libraries. This model provides access to resources, facilities, services, and professional staff. Each part is a necessary component of the overall process of delivering library services at a distance. The home library is the primary source of materials; the offcampus librarian is the primary means of access and delivery; and agreements with nonaffiliated libraries provide an enhancement of library resources and services at a specific location.

In this model, the home library functions as the primary facility for off-campus programs as well as the primary point of access to collections and resources in area libraries. The specific services provided by the main library include a toll-free telephone number, reference and information services, online database searching, book circulation, interlibrary loan, photocopying of journal articles, and document delivery.

Within this model, the designation of a librarian whose only responsibility is the off-campus program and the provision of adequate support staff are basic requirements. Providing library services to offcampus students is labor-intensive and requires highly personalized attention at many levels. The off-campus librarian would serve as a liaison among all components of the off-campus library program. Some of the specific services which this librarian can provide are: reference and information, bibliographic instruction, preparation of specialized bibliographies, compilation and distribution of information packets, faculty orientation to available library services, public relations, marketing and advertising, and evaluation of library services.

At the same time, the primary role of the nonaffiliated libraries is to supplement the resources and services provided by the home library. The agreements with the area libraries are not a substitute for the home library but an enhancement of that library at a specific off-campus site. Some services that these libraries could provide are: reciprocal borrowing privileges, reference and information, reserve reading collection, access to bibliographic tools, bibliographic instruction, and a copy of the home institution's computer-generated card catalog. Reimbursement for services rendered may serve as an incentive for institutions to participate in this kind of cooperative agreement.

As an extension of such a venture, the University of Wyoming, via a Kellogg Foundation grant, has recently implemented a program allowing adults access to libraries in Wyoming, Colorado, Utah, and Montana. Specifically, the Intermountain Community Learning and Information Services program (ICLIS) has formed partnerships between major academic libraries and small, rural public libraries. ${ }^{20}$ Through this arrangement, patrons located in isolated communities can access the holdings of land-grant universities and the state libraries of each participating state.

The bibliographic utilities provide an overall solution to the problem of access, linking technology to the library and to the patron as end-user. Thus they serve as an enhancement for the delivery of offcampus library services in the working model discussed above. For example, libraries currently have access to two of the largest database vendors, Dialog and BRS, and they have the further option of providing access to specific databases directly to the library patron.

The utilities offer immediate advantages for institutions providing off-campus education in that many libraries are already electronically linked to one or more of them. The utilities are interested in expanding their operations through the use of intelligent gateways that allow customized services. ${ }^{21}$ They are more costeffective than alternatives like branch libraries, and they solve many of the problems created by distance and time 
since communications are virtually instantaneous. The utilities offer some immediate advantages to off-campus patrons as end-users by providing access to a wide variety of databases and information services through a dedicated workstation. They facilitate better, more informed choices about resources needed. They make it possible to customize information packages; and they ensure a more rapid turnaround time.

It would be feasible to place terminals in strategic locations at or near a given offcampus site. The nonaffiliated libraries could provide that strategic location. The terminal would give off-campus patrons a means of two-way communication with the home librarian and a means for accessing the home library's collection as well as the collections of other institutions. It might even be possible to use the bibliographic utilities to create a consortium of institutions that are involved in offcampus education and willing to share information to strengthen the community of learning for off-campus patrons.

As an example, the Research Libraries Advisory Committee (RLAD) to OCLC has recently developed a program of reciprocal borrowing for faculty members of research institutions whose libraries are members of OCLC. Through this program, participating institutions provide faculty with on-site access to collections at fifty-eight research libraries. ${ }^{22}$ It would be quite feasible to extend the concept of reciprocal borrowing privileges to offcampus students whose libraries are members of OCLC. The development of such a program would enhance access to collections and provide an added incentive for OCLC membership.

The library services available through this model are intended to meet the full range of bibliographic and information needs of faculty and students. The effectiveness of library services requires periodic review. Procedures should be established for data to be systematically collected and analyzed both to improve existing services and to plan those for the future.

The problems inherent in the delivery of off-campus library services often invite solutions that threaten to curtail the independent learning that libraries have traditionally provided. The academic experience requires that off-campus students gain knowledge of the full range of library materials available in order to decide for themselves what is relevant to their research. As part of the educational process, off-campus students need both to increase their knowledge and to learn to think analytically. This is most likely to happen if off-campus students are encouraged and allowed to assume a share of the responsibility for their own learning process. Offcampus library services have spawned much creative energy toward solving the physical problems of access and delivery. In planning for the future of off-campus library services, academic librarians should emphasize helping off-campus students to become independent self-directed learners. Thus they face both a challenge and an opportunity.

\section{REFERENCES}

1. Barton M. Lessin, ed., Off-Campus Library Services Conference Proceedings, St. Louis, Miss., Oct. 14-15, 1982 (Mount Pleasant, Mich.: Central Michigan Univ. Pr., 1983); Barton M. Lessin, ed., OffCampus Library Services Conference Proceedings. Knoxville, Tenn., Apr. 18-19, 1985 (Mount Pleasant, Mich.: Central Michigan Univ. Pr., 1986).

2. Leland Medsker and others, Extending Opportunities for a College Degree: Practices, Problems, and Potentials (Berkeley: Center for Research and Development in Higher Education, 1975).

3. K. Patricia Cross and Anne-Marie McCartan, Adult Learning: State Policies and Educational Practices. ASHE-ERIC Higher Education Reports 1984, Report 1. (Washington, D.C.: George Washington Univ., Clearinghouse on Higher Education, 1984).

4. Carl Vernon Patton, "Extended Education in an Elite Institution," Journal of Higher Education 46:427-44 (Apr. 1975). 
5. Meredith Ludwig and Gail Latouf, Public Four-Year Colleges and Universities: A Healthy Enrollment Environment? (Washington, D.C.: National Assn. of State Universities and Land Grant Colleges, May 1986).

6. Harold L. Hodgkinson, "Demographics and the Economy: Understanding A Changing Marketplace," Admissions Strategist 4:1-6 (1985).

7. National Center for Educational Statistics, The Condition of Education (Washington, D.C.: U.S. Dept. of Education, 1984).

8. Cross, "Adult Learning," p.17-18.

9. Seymour Lusterman, Education in Industry (New York: The Conference Board, 1977).

10. Robert L. Jacobson, "Stricter Regulations Sought for Off-Campus Programs," Chronicle of Higher Education 14:7-8 (1977).

11. Ibid.

12. Middle States Association of Colleges and Schools, Characteristics of Excellence in Higher Education Standards for Accreditation, 1982; New England Association of Schools and Colleges, Inc., Accreditation Handbook, 1983 ed; North Central Association of Colleges and Schools, A Handbook of Accreditation, 1982; Northwest Association of Schools and Colleges, Accreditation Standards, 1982; Southern Association of Colleges and Schools, Standards of the College Delegate Assembly, 1977; Western Association of Schools and Colleges, Handbook of Accreditation, 1982.

13. State of Connecticut, Board of Governors for Higher Education, Regulations for Licensure and Accreditation of Institutions and Programs of Higher Learning, Mar. 1986.

14. State of North Carolina, Board of Governors, University of North Carolina. Rules and Standards Licensing Non-Public Institutions to Conduct Post Secondary Degree Activity in North Carolina. Revised Sept. 1985.

15. Nova University v. Educational Institution Licensure Commission 483 A.2d 1172 (D.C. App. 1984).

16. Ibid., 1191.

17. "College: The Undergraduate Experience in America," Chronicle of Higher Education 33:21 (Nov. 5,1986).

18. Barton M. Lessin, "Keynote Address," Off-Campus Library Services Conference. Knoxville, Tenn., Apr. 18-19, 1985 (Mount Pleasant, Mich.: Central Michigan Univ. Pr., 1986), p.5.

19. Association of College and Research Libraries, ACRL Guidelines for Extended Library Services, College and Research Library News 47:189-200 (Mar. 1986).

20. Keith M. Cottam, Wyoming ICLIS Activities Report (Laramie, Wyo.: Univ. of Wyoming Libraries, 1987).

21. Stephan Zinn, Martin Sellers, and Debra Bohli, “OCLC's Intelligent Gateway Service: Online Information Access for Libraries," Library High Tech 4:25-29 (Fall 1986).

22. Joan Mouquin, ed., "Reciprocal Borrowing Program for Research Library Faculty," The NELINET Liaison 10:3 (Aug. 1987). 